\title{
Performance Evaluation of Floating Fish Feed Extruder
}

\author{
S. T. Ojo ${ }^{1}$, O. J. Olukunle ${ }^{2}$, T. O. Aduewa ${ }^{3}$ and A. G. Ukwenya ${ }^{4}$ \\ ${ }^{1}$ Department of Agricultural Engineering, Federal University of Technology Akure, P.M.B. 704 Akure, Nigeria. \\ ${ }^{2}$ Department of Agricultural Engineering, Federal University of Technology Akure, P.M.B. 704 Akure, Nigeria. \\ ${ }^{3}$ Department of Agricultural Engineering, Federal University of Technology Akure, P.M.B. 704 Akure, Nigeria. \\ ${ }^{4}$ Department of Agricultural Engineering, Federal University of Technology Akure, P.M.B. 704 Akure, Nigeria.
}

\begin{abstract}
The performance of a developed floating fish feed extruder was evaluated. The effect of some parameters such as; screw speeds (100 rpm, $150 \mathrm{rpm}$, and $200 \mathrm{rpm}$ ), moisture content of ration $(20 \%, 25 \%$, 30 $\%$ and $35 \%)$, and die diameters $(3 \mathrm{~mm}, 5 \mathrm{~mm}, 9 \mathrm{~mm})$ on specific mechanical energy requirements, expansion ratio, bulk density and pelleting efficiency were determined. Results showed that increasing the screw speed from $100 \mathrm{rpm}$ to $150 \mathrm{rpm}$ tend to increase in extrusion efficiency from $63.25 \%$ to $68.50 \%$. And decrease in bulk density from $1.05 \mathrm{~g} / \mathrm{cm}^{3}$ to $0.94 \mathrm{~g} / \mathrm{cm}^{3}$; decrease in specific mechanical energy from $24.70 \mathrm{~kJ} / \mathrm{kg}$ to $22.30 \mathrm{~kJ} / \mathrm{kg}$. By increasing the die diameter from $3 \mathrm{~mm}$ to $5 \mathrm{~mm}$, the specific mechanical energy tends to reduce from 28.44 $\mathrm{kJ} / \mathrm{kg}$ to $26.46 \mathrm{~kJ} / \mathrm{kg}$, reduce bulk density from $1.05 \mathrm{~g} / \mathrm{cm}^{3}$ to $0.97 \mathrm{~g} / \mathrm{cm}^{3}$. And increase extrusion efficiency from $63.25 \%$ to $68.00 \%$. Results also showed that increase in moisture content from $20 \%$ to $25 \%$ tend to reduce the specific mechanical energy from $28.44 \mathrm{~kJ} / \mathrm{kg}$ to $24.99 \mathrm{~kJ} / \mathrm{kg}$, reduce bulk density from $1.05 \mathrm{~g} / \mathrm{cm}^{3}$ to 1.01 $\mathrm{g} / \mathrm{cm}^{3}$. And increase the extrusion efficiency from $63.25 \%$ to $72 \%$.
\end{abstract}

Keywords: extrudates, extruder, evaluation, fish feed, floating and performance

\section{Introduction}

The extrusion process operates in a dynamic steady equilibrium where input variables are balanced with the output. Hence to obtain the required output (extrudate), the dependent physical conditions and chemical process changes must be applied at the correct level. The main system parameters influencing the outputs of extruders include the temperature, mass, resident time, pressure and shear rate depending on extruder geometry, process parameters and raw material composition [1]. According to [2], process parameters like the type of extruder, length of barrel, feed rate, speed, screw configuration; moisture content and so on can also be attributed to the system parameters. Also, viscosity, torque, specific mechanical energy (SME), extrusion pressure, and mass flow rate are identified as momentum transfer parameters [3].

There are four major categories of variables that affect output quality for a given formulation in extrusion system. They include: the extruder screw configuration and length to diameter ratio, die design, diameter, land length, shape, and number of dies on die plate, design of rotation of knife and process variables that the operator can change during the run [4]. The degree of mixing, shear forces introduced, residence time distribution (RTD) and the amount of heat generation by friction are all affected by the extruder configuration. They all affect the degree of cook, the melt rheology, and product uniformity and quality. Understanding the material properties and nature of flow in the die is of paramount issue in controlling the performance and extrudates quality since the die is a major component in the extruder apparatus.

When the texture of the final product is to be considered, the design of the die plays a vital role. The die also helps in stabilizing the flow and shaping of the extruded products. Although, the product quality is generally a function of the die design, design of rotating knife, length to diameter ratio design and the screw configuration.

The screw speed which are between $150-600 \mathrm{rpm}$ depending on the application [5], affects the residence time, the amount of shear introduced, the melt viscosity, amount of frictional energy generated and the barrel fill. The pitch and diameter of the screw, the number of flights and the clearance between the flights and the barrel can each be adjusted to change the performance of the extruder. The moisture content controls the frictional energy generated and the melt viscosity; the feed rate controls the residence time, energy generated and the barrel fill.

The product temperature, which affects the degree of cook and melts rheology, is determined by the temperature profile of the barrel. Product quality attributes are also affected by the induce reaction of the intermediate process parameters like the screw speed, die geometry, barrel temperature among others [6].

\section{Methodology}

The extruder was evaluated for performance in terms of some system and product parameters. 


\subsection{System Parameter}

Product Temperature: The temperature of the product was determined as described by [4]. This parameter was measured with TECPEL digital thermocouple 307B, inserted into the melt before passage of the material out of the die. This represents the thermal energy.

Specific Mechanical Energy Requirement (SME): This is a measure of the work done by the extruder on the feed materials; the energy that is transformed into the thermal energy; an important index in terms of the cost of manufacturing extruded products. SME according to [7], it was calculated using the equation below:

$$
\mathrm{SME}=\frac{2 \pi x \tau x \mathrm{sg} / 60}{\mathrm{Fr}} X 3.6\{\mathrm{KJ} / \mathrm{Kg}\}
$$

Where; $\tau$ is the corrected torque $(\mathrm{Nm}), \mathrm{Ss}$ is the screw speed $(\mathrm{rpm}), \mathrm{Fr}$ is the feed rate $(\mathrm{Kg} / \mathrm{h})$. The torque $\tau$ required to drive the screw was calculated using the equation below according to [8].

$$
\tau=\frac{60 P}{2 \pi N}
$$

And,

$$
\mathrm{P}=\frac{P_{\text {th }}}{\eta}
$$

Where, $\mathrm{P}$ is the input power, $\mathrm{\eta}$ is the extruder efficiency, $P_{\mathrm{th}}$ is the theoretical power required by the extruder, $\mathrm{N}$ is the machine speed in rpm, $\mathrm{T}$ is the torque required.

\subsection{Extruder Efficiency}

The extruder efficiency was evaluated by determining parameters like the extrusion capacity and functional/extrusion efficiency of the machine from the observed data.

Extrusion capacity was calculated according to [9] using the equation below:

$$
\mathrm{EC}=\frac{\mathrm{Me}}{T}
$$

Where; EC is the extrusion capacity $(\mathrm{Kg} / \mathrm{min}), \mathrm{M}_{\mathrm{e}}$ is the mean mass of the extrudates for each treatment $(\mathrm{Kg}), \mathrm{T}$ is the mean time taken for the extrusion $(\mathrm{min})$. Extrusion/functional efficiency were calculated as the ratios in percentage of the extrudates to the initial mass of materials fed into the machine. This is represented mathematically as:

$$
\mathrm{RE}=\frac{M e}{M i}
$$

Where; $R E$ is the extrusion efficiency (\%), $\mathrm{M}_{\mathrm{e}}$ is the mean mass of extrudates $(\mathrm{Kg}), \mathrm{M}_{\mathrm{i}}$ is the mean initial mass of ingredients (kg) [9]; [10].

\subsection{Product Parameters}

Product Moisture Content: The moisture contents of the extruded feed were determined on dry basis by an oven drying method. About $10 \mathrm{~g}$ of each sample were dried in an oven at about $100 \pm 2^{\circ} \mathrm{C}$ for about 18 hours. A Philip Essence HR 2394 measuring balance made in Hungry was used in weighing the extrudates before and after the drying and allowed to cool in a desiccators to determine the loss in weight which also represents moisture loss.

Expansion Ratio: This was determined according to [11] were extrudates are measured using Vernier caliper and the radial expansion ratio calculated from the formula below:

$$
\mathrm{E}_{\mathrm{r}}=\frac{\mathrm{D}^{\mathrm{z}}}{\mathrm{d}^{\mathrm{z}}}
$$

Where; $\mathbf{E}_{\mathbf{r}}$ is the expansion ratio, $\mathbf{D}$ is the extrudates diameter while $\mathbf{d}$ is the diameter of the die.

\subsection{Experimental Plan}

This experiments was conducted using a factorial design comprising of three levels of initial moisture content, three levels of screw speed and three levels of die nozzles which were replicated three times. The three independent variable levels were pre-selected based on the results of the preliminary tests.

\subsubsection{Test Parameters}

The performance criteria considered are the product temperature, Specific Mechanical Energy (SME), expansion ratio, torque. The performance variables include the constant variables (screw configuration and feed rate) while the running variables are described below:

- Four levels of initial moisture content; $20 \%, 25 \%, 30 \%$ and $35 \%$ (d.b)

- Three levels of screw speed; $100 \mathrm{rpm}, 150 \mathrm{rpm}$ and $200 \mathrm{rpm}$

- Three levels of die nozzles; $3 \mathrm{~mm}, 5 \mathrm{~mm}$ and $9 \mathrm{~mm}$

A formulation was used so as to know the effect of various running variables on the product quality characterization of the extrudates. Three replicates were carried out for each treatment; statistical tests were 
conducted using Microsoft Excel (copywrite, 2007). Graphical plots and diagrammatic representations were also generated using the aforementioned tool.

\subsection{Sample Preparation}

Native cassava starch was used to replace the GNC - Groundnut cake because of it lighter density to function as the binder, other materials with lesser bulk densities compared to that of water like wheat offal, rice bran, corn, soya and so on were sources locally and powdered to enhance higher degree of compactivity during extrusion. These various products were gotten from Dotak Feed Mill, custom; Ondo road Akure, Nigeria except the starch that was gotten from the Akure main market.

During the feed preparation, the yellow corn, soya, rice bran and wheat were milled to powder to increase their surface area and enhance better adhesion between the particles. The experimental ration used was in the composition as shown below; the mixing was done manually as a result of the lack of required machine that could be used. The moisture content of the ration was determined on a dry basis by placing about $20 \mathrm{~g}$ of the mixed ration was placed in an oven at about $100 \pm 2{ }^{\circ} \mathrm{C}$ for about 18 hours. The dried sample was then reweighted to determine the moisture loss from the weight loss.

\section{Table 1:Composition of Experimental Ration}

\begin{tabular}{ll}
\hline Composition & Percentage $(\%)$ \\
\hline Yellow corn & 12 \\
Soya bean & 17 \\
Wheat bran & 40.5 \\
Fish meal & 12 \\
Fish oil & 3 \\
Starch & 15 \\
Premix & 0.3 \\
Lysine & 0.2 \\
\hline
\end{tabular}

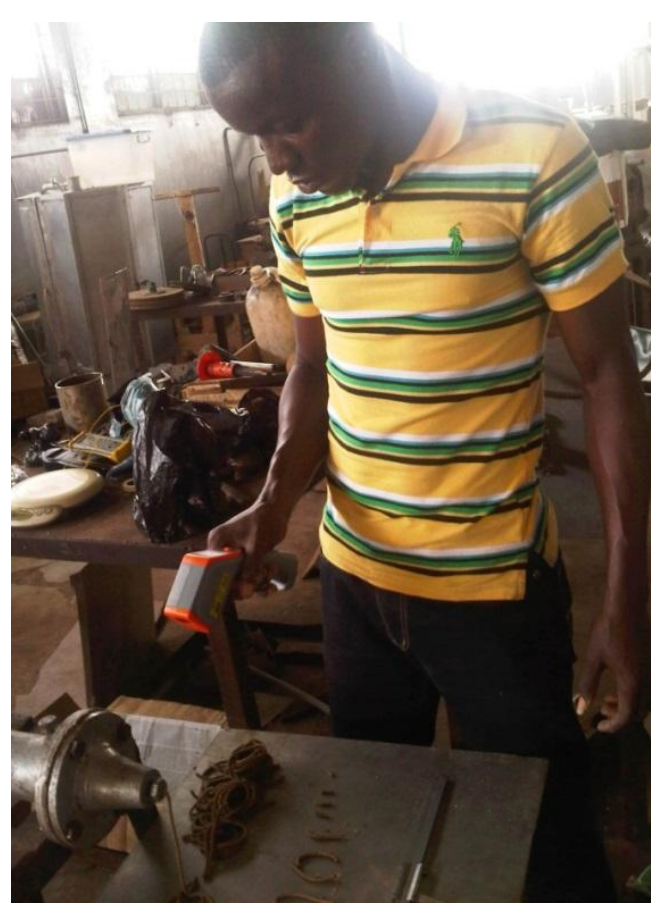

Plate 1: Pictorial view of one of the extrusion process while taking barrel temperature 


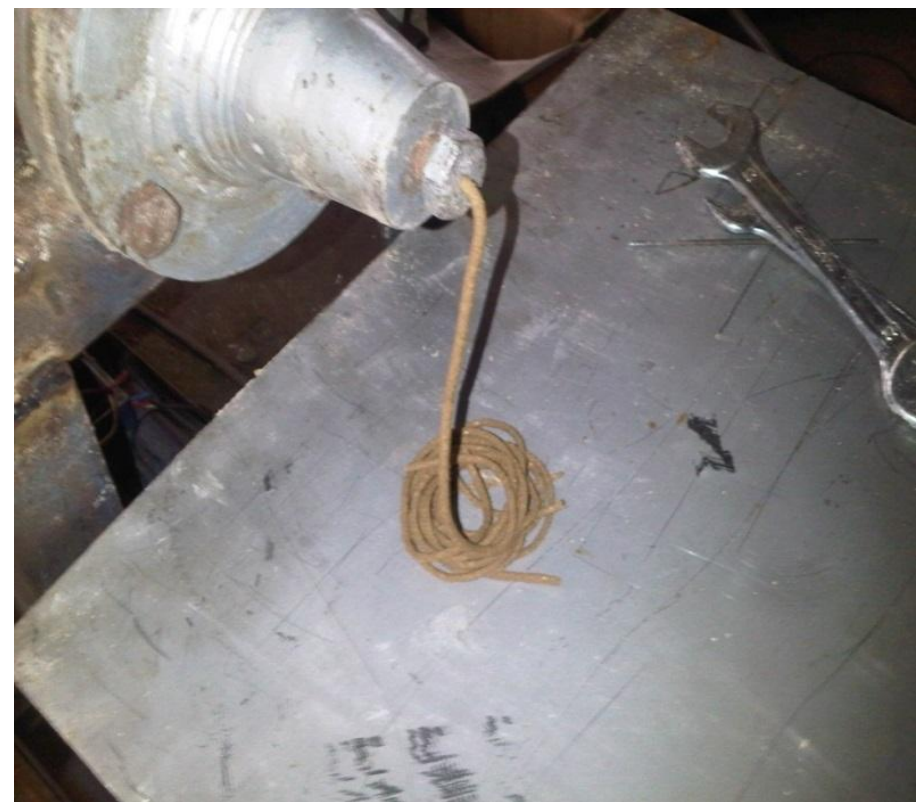

Plate 2: pictorial view showing extrusion of extrudate from the extruder

\subsection{Effect of Extrusion Variables}

\section{Results And Discussion}

The effect of extrusion variables under study were quantified using some system and product quality parameters. Two system parameters namely: temperature \& Specific Mechanical Energy; and two product parameters namely: product moisture content \& expansion ratio were used. The results are discussed as follows:

\subsubsection{Effect of Extrusion Variables on System Parameters}

The system parameters studied includes the product temperature and the specific mechanical energy requirement. Product temperature according to [5] is a suitable parameter for a system analysis of extrusion cooking.

\subsubsection{Effect of extrusion variables on product temperature.}

When the machine was operated at the constant speed of $150 \mathrm{rpm}$ at varying die diameters and moisture content, different results were observed. For $3 \mathrm{~mm}$ die diameter, extrusion began at about 6 minutes for $20 \%$ and $25 \%$ moisture content and at about 8 minutes for $30 \%$ moisture content. There was no significant difference in the plotted curves for the product temperature for $20 \%$ and $25 \%$ moisture content while the curve from the product temperatures from material with $30 \% \mathrm{MC}$ was below that of $20 \%$ and $25 \% \mathrm{MC}$.

For $5 \mathrm{~mm}$ diameter, extrusion begins at about the same time with when the machine was operated at $150 \mathrm{rpm}$ and $3 \mathrm{~mm}$ die diameter. The observed temperature was slightly higher for $25 \% \mathrm{MC}$ compared to that of $20 \% \mathrm{MC}$ as the duration of extrusion tend toward 30 minutes. The temperature curve for $30 \% \mathrm{MC}$ was slightly below the other two.

For $9 \mathrm{~mm}$ die diameter, extrusion began at about 6 minutes for all the moisture contents. The temperature for $20 \% \mathrm{MC}$ was higher than others between 9 to 21 minutes of extrusion before it was overtaken by the temperature of $25 \% \mathrm{MC}$ at about 24 minutes. The temperature for $30 \% \mathrm{MC}$ increases with increase in extrusion duration between 6 to 24 minutes beyond which, the temperature remained almost constant. Fig. 1 shows the variations.

The highest temperature of $103.2{ }^{\circ} \mathrm{C}$ was observed when the extruder was operated at the speed of 150 rpm with $3 \mathrm{~mm}$ die diameter and the moisture content of the fed material was $25 \%$. The lowest temperature of $53{ }^{\circ} \mathrm{C}$ was recorded when the extruder was operated at the speed of $200 \mathrm{rpm}, 9 \mathrm{~mm}$ die diameter and the moisture content of the fed materials was $30 \%$.

The obtained results showed that product temperature increases with increase in the duration of extrusion. The increase in die diameters led to decrease in product temperature which could have been from the reduction in the pressure built-up as a result of the increased discharge outlet from the larger nozzle diameter. This conformed to [12]. It was also observed that the product temperature decreases with increase in moisture content which was also supported by [13]. 


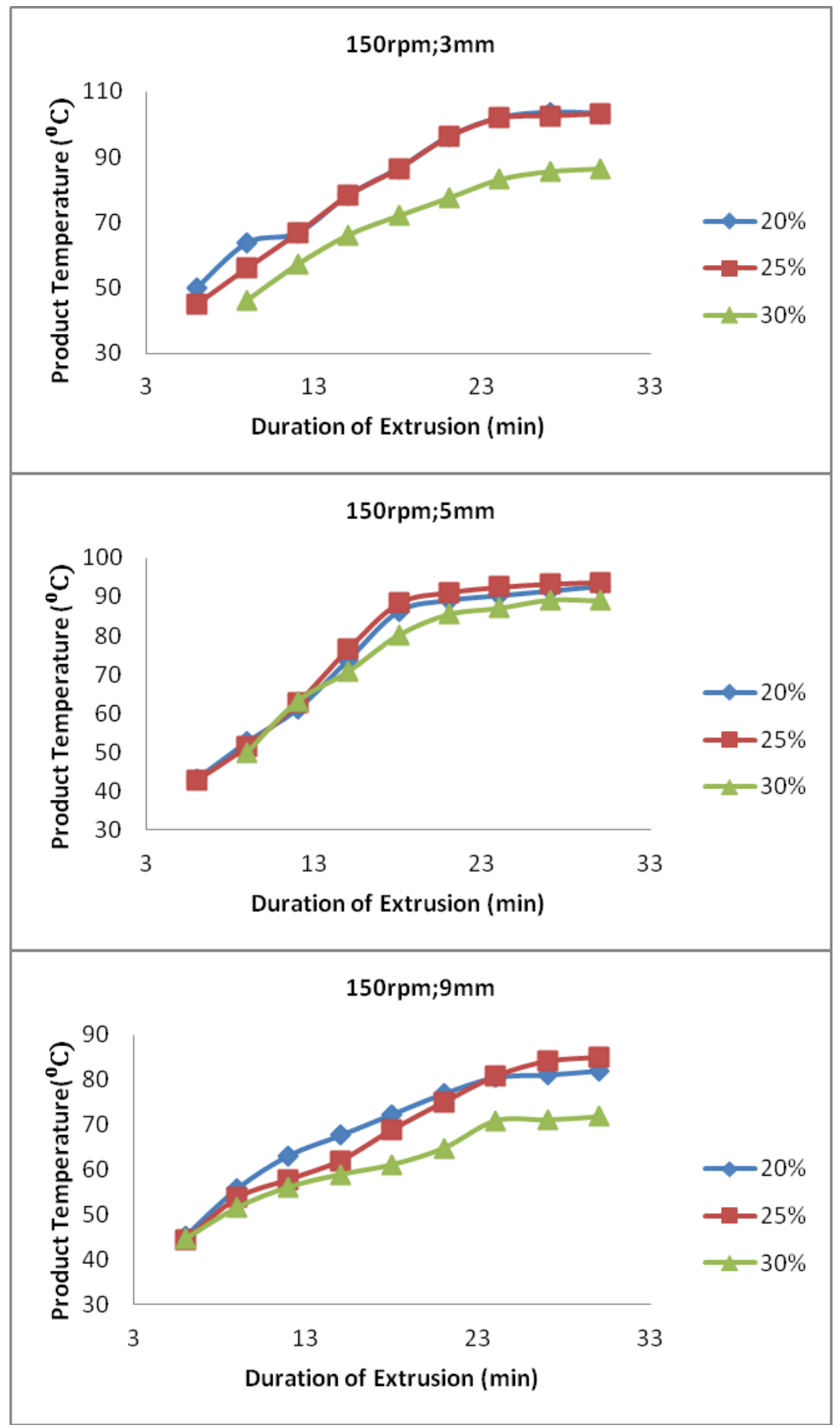

Figure 1: Variations in products temperature with extrusion time at a constant machine speed of $150 \mathrm{rpm}$ and varying die diameters and varying moisture contents.

\subsubsection{Effect of Extrusion Variables on System Mechanical Energy}

The System Mechanical Energy is a common measure of the extrusion energy consumption which indicates the relative ease with which a material can be extruded. The increase in the machine speed from 100 $\mathrm{rpm}$ to $150 \mathrm{rpm}$ when the die diameter and the material moisture content were kept constant, it was observed that the specific mechanical energy decreases. $(28.44 \mathrm{~kJ} / \mathrm{Kg}$ to $26.21 \mathrm{~kJ} / \mathrm{Kg}$ for $3 \mathrm{~mm}$ die diameter; $20 \%$ moisture content, $24.70 \mathrm{~kJ} / \mathrm{Kg}$ to $22.30 \mathrm{~kJ} / \mathrm{Kg}$ for $5 \mathrm{~mm}$ die diameter; $25 \%$ moisture content to mention a few). Further increment in the machine speed from $150 \mathrm{rpm}$ to $200 \mathrm{rpm}$ when other variables were kept constant, a decrease in system mechanical energy were observed except for when the machine was operated with $3 \mathrm{~mm}$ die 
diameter and $20 \%$ moisture content which acted otherwise. The fig. 2 is the graphical representation for system mechanical energy in response to the varying parameters.

The decrease in System Mechanical Energy which was observed when the machine was increased from $150 \mathrm{rpm}$ to $200 \mathrm{rpm}$ at $150 \mathrm{rpm}$ with $3 \mathrm{~mm}$ die diameter and $20 \%$ moisture content which was in contrast with the response for others could have been from the machine trying to extrude more materials through a small orifice. It was also observed that increase in die diameter when other variables were kept constant led to decrease in the System Mechanical Energy of the machine as supported by [12] and [14].

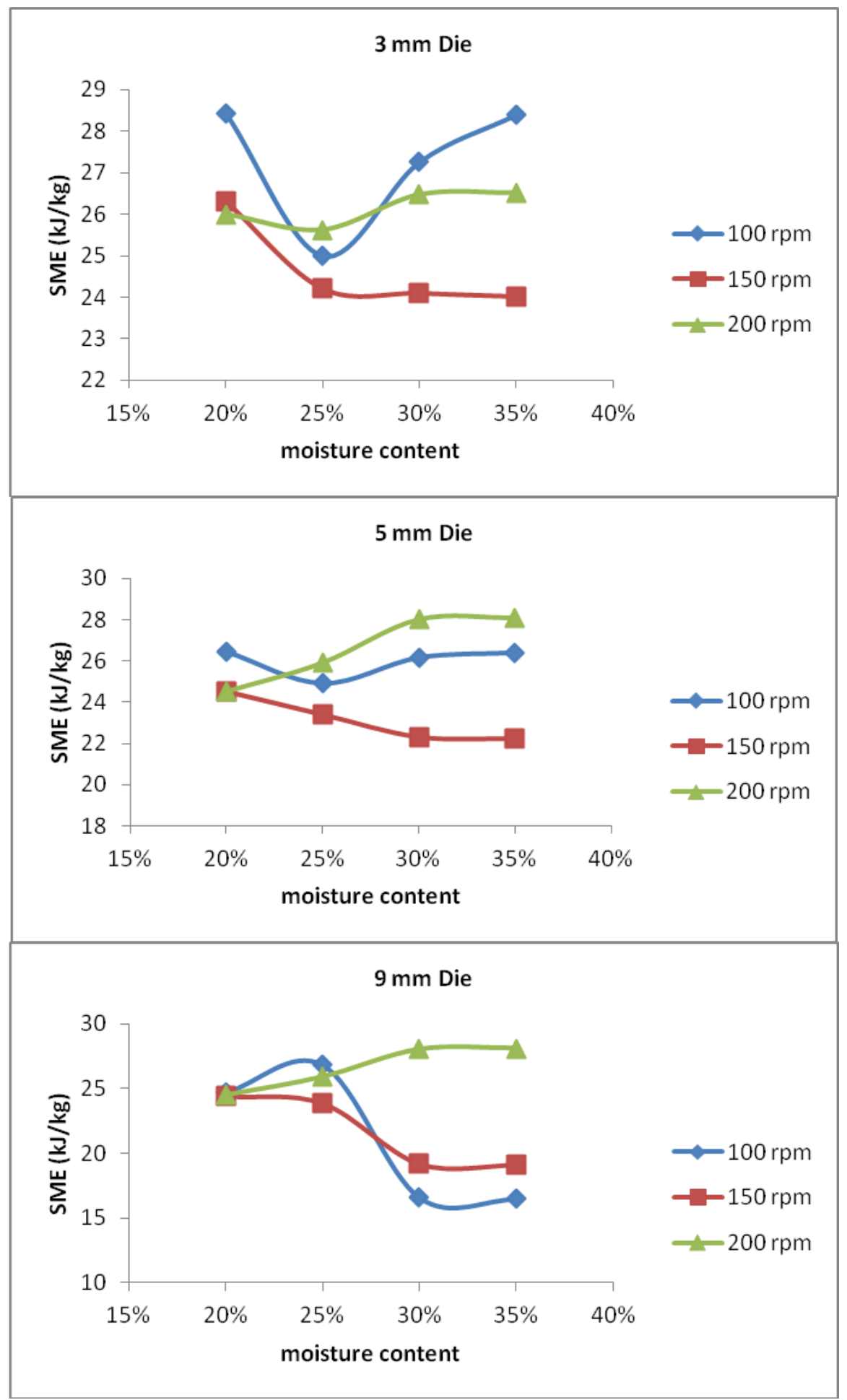

Figure 2 Graphs for system mechanical energy versus duration of extrusion of varying die diameters for the various moisture contents. 


\subsection{Extruder Efficiency}

When the machine was operated at $3 \mathrm{~mm}$ die diameter, the machine efficiency for the various speed increases as moisture content of the materials were increased from $20 \%$ to $25 \%$. While there were decreases in the efficiency on further increase in the moisture content from $25 \%$ to $35 \%$. It was also observed that the increase in machine speed from $100 \mathrm{rpm}$ to $150 \mathrm{rpm}$ led to an increase in extrusion efficiencies except when the machine was operated with $5 \mathrm{~mm}$ die diameter from $72.75 \%$ to $67 \%$. Fig. 3 shows the graph for extrusion efficiencies of the developed machine against varying moisture content varying machine speed and die diameters.

It was observed that further increase in the machine speed from $150 \mathrm{rpm}$ to $200 \mathrm{rpm}$ led to a decrease in extrusion efficiencies as reported by [14] except when the machine was operated with $9 \mathrm{~mm}$ die diameter and there was an increase in the efficiency from $67 \%$ to $72.25 \%$. It was also observed that the efficiencies at $20 \%$ moisture content were higher than the efficiencies at $35 \%$ moisture content. The highest extrusion efficiency of $80.5 \%$ was recorded when the machine was operated at $150 \mathrm{rpm}$ machine speed, $5 \mathrm{~mm}$ die diameter at $25 \%$ moisture content while the lowest machine efficiency of $63.25 \%$ was recorded when the machine was operated at $100 \mathrm{rpm}$ machine speed, $3 \mathrm{~mm}$ die diameter at $20 \%$ moisture content.

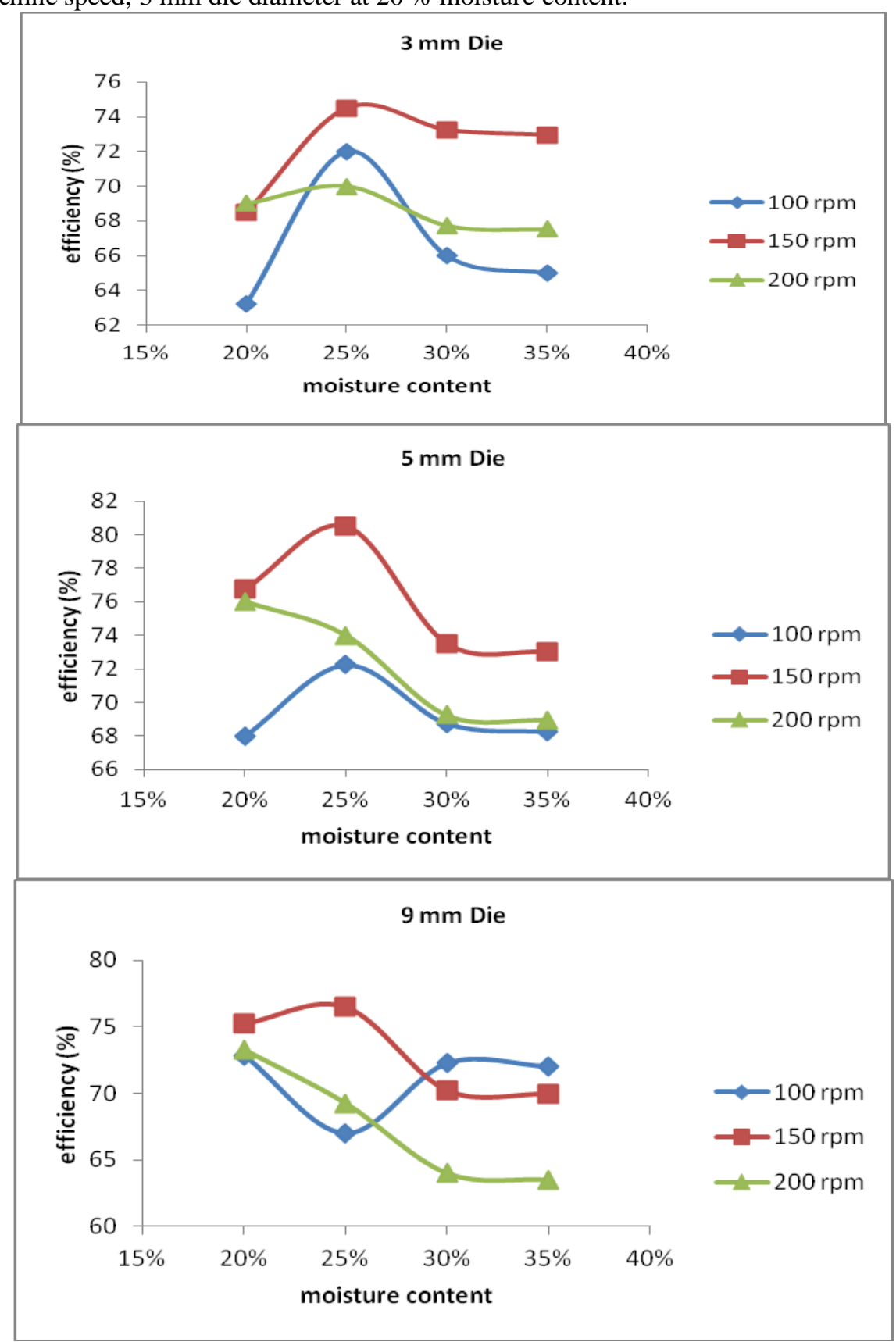

Figure 3 Graphs for extrusion efficiencies of the developed machine against varying moisture content, varying machine speed and die diameters. 


\subsection{Product Quality Attribute}

The product quality attributes studied include the product moisture content and the expansion ratio.

\subsubsection{Effect of extrusion variables on product moisture content}

Fig. 4 shows the relationship between product moisture content and initial moisture content. The relationship between the two afore mentioned variables is a direct proportionality that is, as one increases, the other also increases. It was observed that the product moisture content decreases from $100 \mathrm{rpm}$ to $150 \mathrm{rpm}$ but it creases from $150 \mathrm{rpm}$ to $200 \mathrm{rpm}$ this must have been as a result of the less time spent by the materials in the extruder when the machine was been operated at $200 \mathrm{rpm}$ thus not giving enough room for the extruder temperature to act proper on the materials. The product moisture was directly proportional to the die nozzle diameter. The increase in the die nozzle encourages increase in the product temperature. The highest product moisture content of $30 \%$ was observed when the extruder was operating at the speed of $200 \mathrm{rpm}$; die diameter of $9 \mathrm{~mm}$ and the initial moisture content of the materials fed $35 \%$.

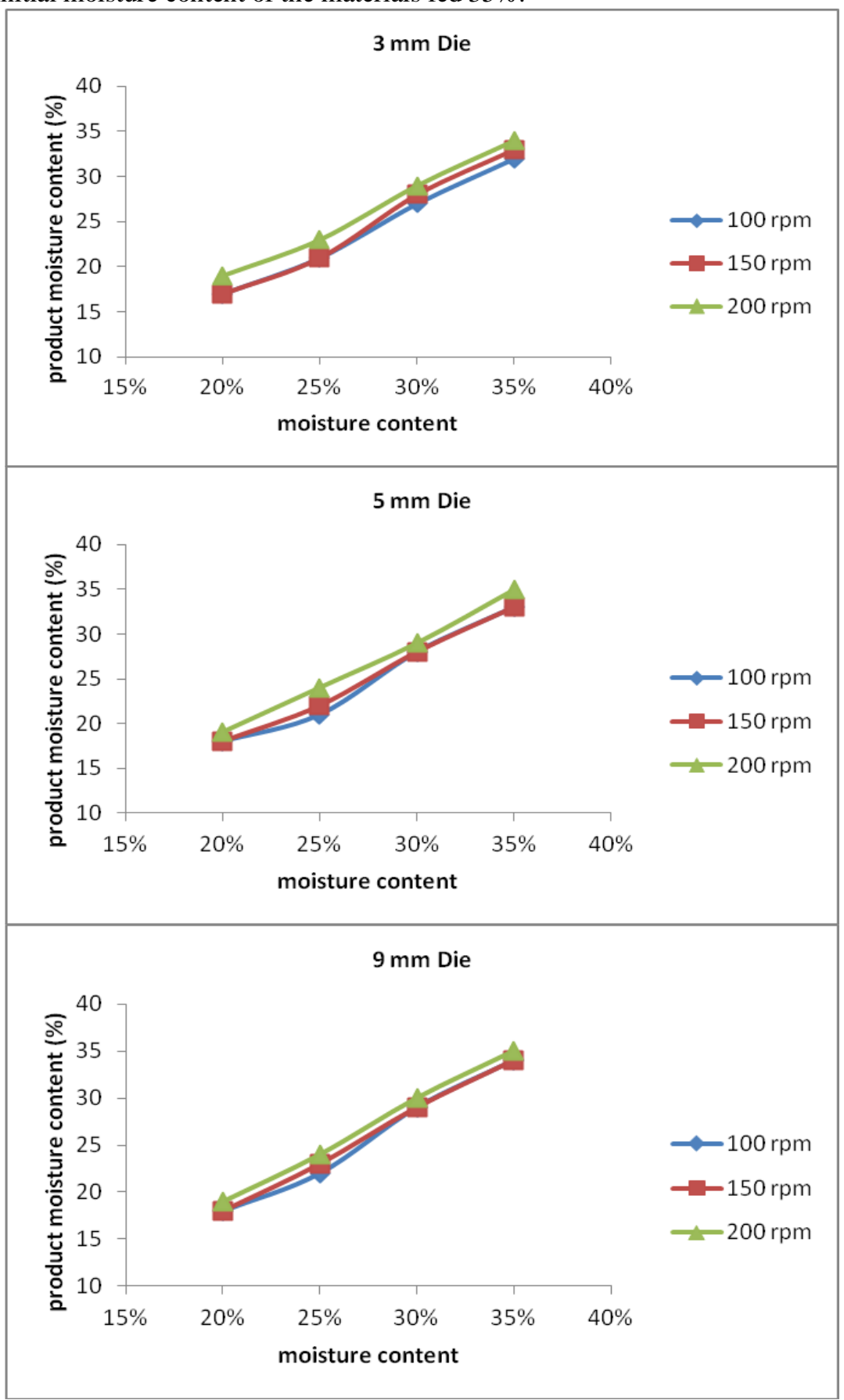

Figure 4 Relationships between product moisture content and initial moisture content for various die diameters and machine speeds. 


\subsubsection{Effect of extrusion variables on expansion ratio}

When the machine was operated at the constant speed of $150 \mathrm{rpm}$ at varying die diameters and moisture content, different results were observed.

The expansion ratios were high when the machine was operated with $3 \mathrm{~mm}$ and $5 \mathrm{~mm}$ die diameters. For $25 \%$ moisture content with $3 \mathrm{~mm}$ die diameter at $150 \mathrm{rpm}$ speed, extrusion began at about 6 minutes but expansion became noticeable at about 9 minutes of extrusion and above. While for $20 \%$ and $30 \%$ moisture content, extrusion began at about 9 minutes while expansion became notice able from 12 minutes and above. It was observed that the expansion ratio was relatively low for $9 \mathrm{~mm}$ die diameter. The relationships between expansion ratio against duration of extrusion for $150 \mathrm{rpm}$ speed at varying die diameters and moisture contents is shown in the Fig. 5.

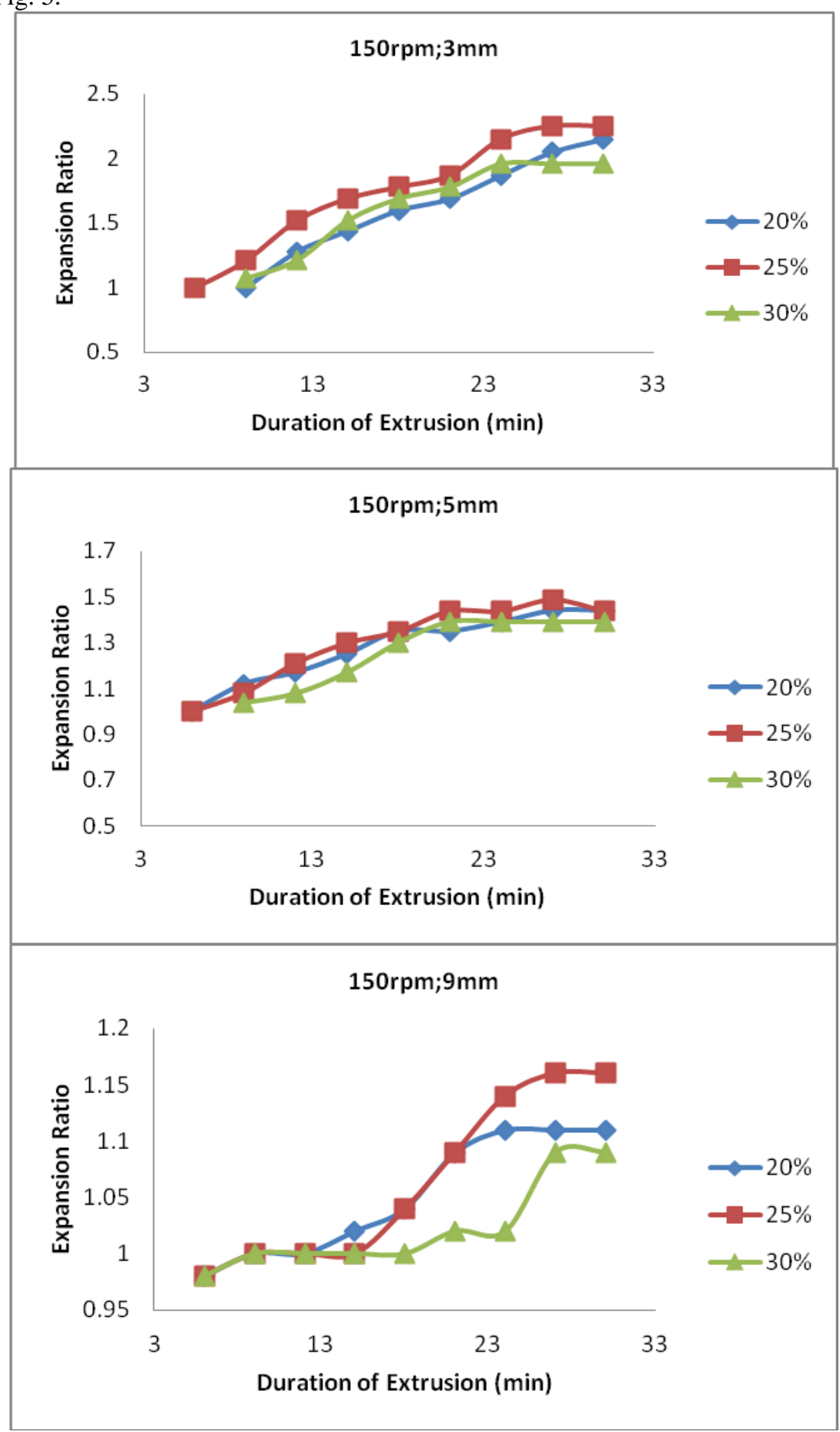

Figure 5 Relationships between expansion ratio against duration of extrusion for $150 \mathrm{rpm}$ speed at varying die diameters and moisture contents. 


\subsection{Bulk Density}

When the machine was operated with $3 \mathrm{~mm}$ die diameter; highest bulk density range were gotten for $100 \mathrm{rpm}$ speed compared to when the speeds were $150 \mathrm{rpm}$ and $200 \mathrm{rpm}$. There was a distinct difference in the bulk densities recorded for the varying speed. For $5 \mathrm{~mm}$ and $9 \mathrm{~mm}$ die diameter, when the machine was operated at $150 \mathrm{rpm}$ and $200 \mathrm{rpm}$, close bulk density range was recorded. Figure 6 below show the relationship between the bulk density and moisture content for varying speed and die diameters.

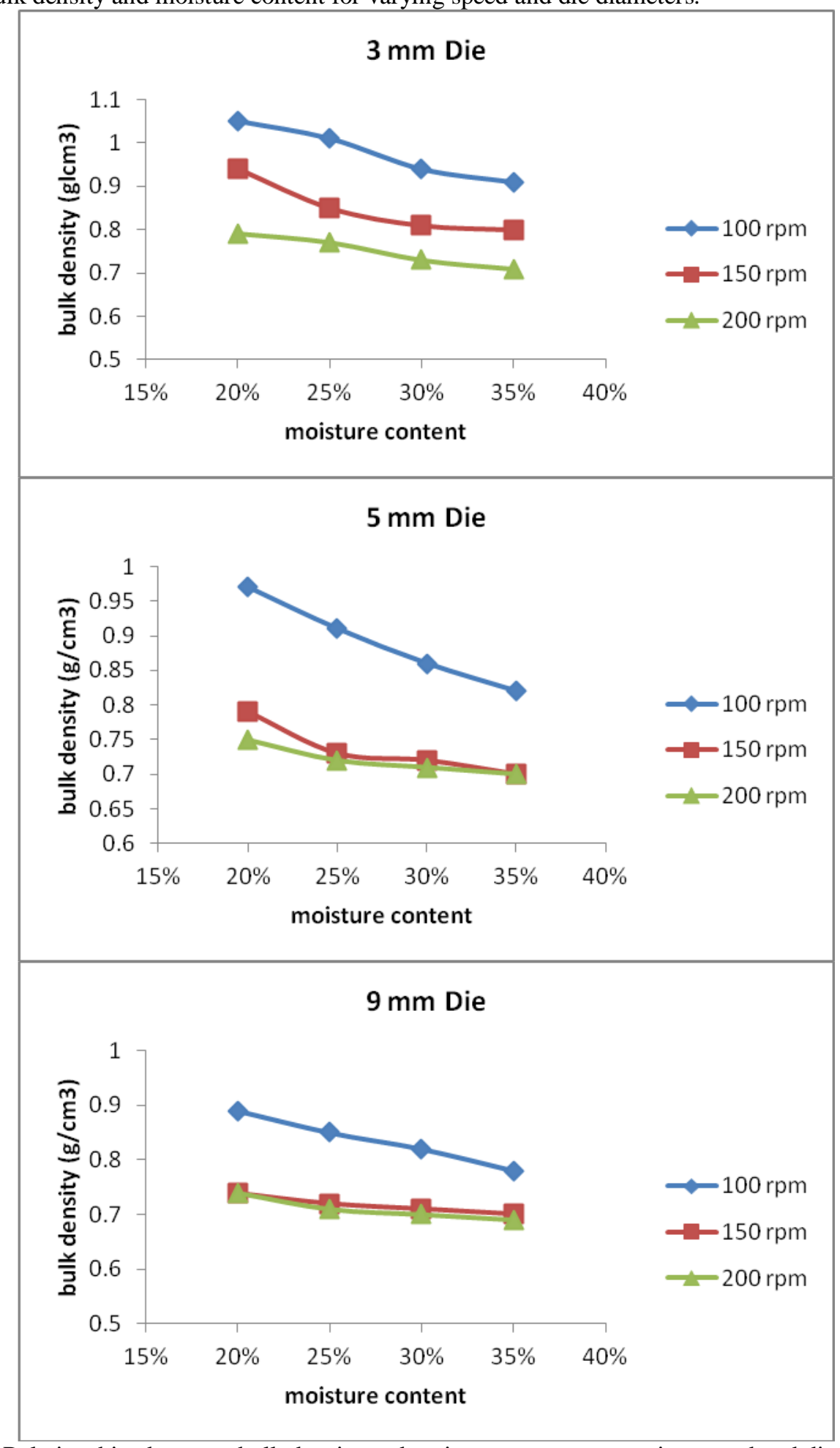

Figure 6 Relationships between bulk density and moisture content at varying speed and die diameters.

It was observed generally that as the speed increases, the bulk density reduces. This decrease in the bulk density could be as a result of the decrease in the time spent by the material within the extruder chamber 
due to the speed. It was also observed that as the moisture content increases, the bulk density decreases which conform to Hamada et al., 2008. The increase in die diameter also reduces the bulk density. This reduction in bulk density could be as a result of the decrease in the pressure inside the extruding unit as a result of the larger orifice from the increased die diameter.

\section{Conclusions}

A developed extruded have been evaluated for performance in terms of the system and product parameters. Results showed that increasing the screw speed from $100 \mathrm{rpm}$ to $150 \mathrm{rpm}$ tend to increase in extrusion efficiency from $63.25 \%$ to $68.50 \%$. And decrease in bulk density from $1.05 \mathrm{~g} / \mathrm{cm}^{3}$ to $0.94 \mathrm{~g} / \mathrm{cm}^{3}$; decrease in specific mechanical energy from $24.70 \mathrm{~kJ} / \mathrm{kg}$ to $22.30 \mathrm{~kJ} / \mathrm{kg}$. Further increase in the screw speed from $150 \mathrm{rpm}$ to $200 \mathrm{rpm}$ tends to reduce extrusion efficiency from $74.50 \%$ to $69.00 \%$, decrease bulk density from $0.85 \mathrm{~g} / \mathrm{cm}^{3}$ to $0.79 \mathrm{~g} / \mathrm{cm}^{3}$. And increase in specific mechanical energy from $24.10 \mathrm{~kJ} / \mathrm{kg}$ to $26.00 \mathrm{~kJ} / \mathrm{kg}$.

Results showed that increase in moisture content from $20 \%$ to $25 \%$ tend to reduce the specific mechanical energy from $28.44 \mathrm{~kJ} / \mathrm{kg}$ to $24.99 \mathrm{~kJ} / \mathrm{kg}$, reduce bulk density from $1.05 \mathrm{~g} / \mathrm{cm}^{3}$ to $1.01 \mathrm{~g} / \mathrm{cm}^{3}$. And increase the extrusion efficiency from $63.25 \%$ to $72.00 \%$. Further increase in moisture content from $25 \%$ to 30 $\%$ tends to increase the specific mechanical energy from $24.99 \mathrm{~kJ} / \mathrm{kg}$ to $27.26 \mathrm{~kJ} / \mathrm{kg}$. And reduce extrusion efficiency from $72.00 \%$ to $66.00 \%$, reduce bulk density from $1.01 \mathrm{~g} / \mathrm{cm}^{3}$ to $0.94 \mathrm{~g} / \mathrm{cm}^{3}$.

By increasing the die diameter from $3 \mathrm{~mm}$ to $5 \mathrm{~mm}$, the specific mechanical energy tends to reduce from $28.44 \mathrm{~kJ} / \mathrm{kg}$ to $26.46 \mathrm{~kJ} / \mathrm{kg}$, reduce bulk density from $1.05 \mathrm{~g} / \mathrm{cm}^{3}$ to $0.97 \mathrm{~g} / \mathrm{cm}^{3}$. And increase extrusion efficiency from $63.25 \%$ to $68.00 \%$. Further increase in the die diameter from $5 \mathrm{~mm}$ to $9 \mathrm{~mm}$, tend to reduce specific mechanical energy from $26.46 \mathrm{~kJ} / \mathrm{kg}$ to $24.73 \mathrm{~kJ} / \mathrm{kg}$, reduce bulk density from $0.97 \mathrm{~g} / \mathrm{cm}^{3}$ to $0.86 \mathrm{~g} / \mathrm{cm}^{3}$. And increase the extrusion efficiency from $68.00 \%$ to $72.75 \%$.

Different parameters involved in the extrusion process (machine speed, moisture content of the fed materials and the die diameters) are important and interrelated. The study revealed that it is better to fix the extrusion variable at the moderate values to enhance the extrusion performance.

\section{Reference}

[1]. Kitabatake, N., Megard, D., and Cheftel, J.C., (1985). Continuous Gel Formation by Extrusion-Cooking: Soy Proteins. Journal of Food Science, 49, 453-458.

[2]. Kokini J.L., Ho C.T., and Karwe M.V. Eds. (1992). Food Extrusion Science and Technology, Pp. 770 New York Marcel Dekker

[3]. Lam, C.D., and R.A. Flores, (2003). Effect of Particle Size and Moisture Content on Viscosity of Fish Feed. Cereal Chem. 80: 20 24

[4]. Chessari, C.J. and Sellahewa, J.N., (2001). Effective Process Control in Guy, R (2001) (Ed) Extrusion Cooking Technologies and Applications. (Wood Head Publishing Limited and Crc Press LLC, Cambridge, England).

[5]. Fayose, F.T., (2009). Development and Performance Evaluation of a Starch Extruder, Unpublished P.hD. Thesis, Federal University of Technology, Akure.

[6]. Guy, R.C.E., (2001). Raw Materials for Extrusion Cooking. in R. C. E. Guy (Ed.), Extrusion Cooking Technologies and Applications (Pp. 5-28, 89). Cambridge, UK: Woodhead Publishing Limited.

[7]. Chi-Chuang and Yen., (2004). Cited in Fayose, F.T. (2009). Development and Performance Evaluation of a Starch Extruder, Unpublished P.hD. Thesis, Federal University of Technology, Akure.

[8]. Khurmi, R.S., (2006). Strength of Materials (Mechanics of Solids) S.I. Units. (S. Chand and Company Ltd. New Delhi), Pg. 765.

[9]. Kabri, M.M., Ahmed, M.M.Z., Azam, M.H. and Jakobsen, F., (2006). Single-Screw Extrusion of Parley-Grape Pomace Elnds: Extrudate Characteristics and Determination of Optimum Processing Conditions. Journal of Food Engineering, V. 89, N. 1, P. 24-32.

[10]. Olukunle, O.J., and Akinnuli B.O. Performance Evaluation of a Single Action Cassava Peeling Machine in Scholarlink Research Institute Journals ISSN: 946-2141-7016

[11]. Choudhury, G. S. and Gautam, A., (1998). Comparative Study of Mixing Elements During Twin- Screw Extrusion of Rice Flour, Food Res. Intl., Vol. 31, No. 1, Pp. 7-17.

[12]. Kaddour, U.A.K.; T.R. Awes and M.K Afify, (2006). Influencing of Geometric Dimension of Extrusion Die Holes on Machine Efficiency and Pellets Quality. Conference of Mansoura University, Journal of Agricultural Science. 31 (7): $337-359$.

[13]. Kaddour, U.A., T.R. Owies and H.A. El-Gendy., (2005). A Study on the Effect of Using Steam-Lock in Extruder Pelleting Machine to Produce Floating Fish Feed Pellets. Misr J.Ag.Eng.,22(4):266-293.

[14]. Morad, M.; M.K. Afify, U. Kaddour, and V.M. Daood, (2007). Study on Some Engineering Parameters Affecting the Performance of Fish Feed Pelleting Machine. Misr J.Ag.Eng., 24(2): 259-282. 